\title{
THREATENED FISHES OF THE WORLD: Coptodon walteri (Thys van den Audenaerde 1968) (Perciformes: Cichlidae)
}

\section{Felix Koffi Konan*, Richard Jean Olive Doffou, Yves Kotchi Bony, Gustave N'guessan Aliko, Emmanuel N'guessan Assemian}

Department of Environment, University Jean Lorougnon Guédé, BP 150 Daloa, Ivory Coast

*Corresponding Author, Email: konanfelix@yahoo.fr

\section{ARTICLE INFO}

Received: 21 December 2015

Received in revised form: 15 April 2016

Accepted: 29 April 2016

Available online: 16 May 2016

\begin{abstract}
Coptodon walteri Thys van den Audenaerde 1968, an endemic cichlid of Ivory Coast and Liberia, is assessed as Near Threatened due to fishing pressure and loss of habitats, and aquatic pollution as a result of extensive clandestine gold mining in the bed of the Cavally River. There is an immediate need for developing conservation and management plans for this species.
\end{abstract}

Keywords:

Tilapia walteri

Cichlid

Near threatened

West Africa

How to Cite

Konan, F. K., Doffou, R. J. O., Bony, Y. K., Aliko, G. N., Assemian, G. N. (2016): Threatened fishes of the world: Coptodon walteri (Thys van den Audenaerde 1968) (Perciformes: Cichlidae). Croatian Journal of Fisheries, 74, 84-86. DOI: $10.1515 / \mathrm{cjf}-2016-0014$

\section{SYNONYMS}

Tilapia walteri Thys van den Audenaerde 1968 (Dunz and Schliewen, 2013; Eschmeyer et al., 2016).

\section{COMMON NAMES}

Freshwater carp or tilapia (English). "Kho" (in Yacouba, ethnic group in western Ivory Coast).

\section{TAXONOMIC NOTES}

Described as Tilapia walteri from the Cavaly River, Western Africa (Thys van den Audenaerde 1968). A recent study on the molecular phylogeny and classification of the haplotilapiine cichlid fishes (Dunz and Schliewen, 2013) revised the generic status of the fish to Coptodon walteri.

\section{GEOGRAPHIC RANGE INFORMATION}

Coptodon walteri (Fig. 1) has a very restricted distribution in the west of Ivory Coast (in the Cavally and Nipoué (Cess) Rivers) and East Liberia (St. John River) where they are endemic (Teugels and Thys van den Audenaerde, 1991, $1992,2003)$. The total range of the species is estimated to be less than 1500 km² $^{2}$ Holland et al., 2012; IFC, 2012; IUCN, 2014).

\section{FISHERY AND POPULATIONS}

Frequently present in artisanal fisheries in the Cavally River in Danané, Zouan-Hounien and Bin-Houyé in the western Ivory Coast (Doffou, 2014; Konan, 2015; Konan et al., 2015) where $C$. walteri is one of the most abundant fish species caught using fish traps. 
In Danané region (western Ivory Coast), C. walteri represented $5.4 \%$ of the total fish abundance. The total length and weight of this species ranged from $47 \mathrm{~mm}$ to $270 \mathrm{~mm}$, and $2 \mathrm{~g}$ to $264 \mathrm{~g}$, respectively (Teugels and Thys van den Audenaerde, 1991; 1992; 2003; Konan, 2015; Konan et al., 2015).

\section{HABITAT AND ECOLOGY}

A benthopelagic species that inhabits rivers with temperature between $24^{\circ} \mathrm{C}-26^{\circ} \mathrm{C}$ (Baensch and Riehl, 1995) where they are mostly found in clear water areas with canopy cover of around $50 \%$ and clay silt, mud, sand and other debris as the substrate.

\section{BIOLOGY}

Size and age at first sexual maturity of C. walteri is 169 $\mathrm{mm}$ in total length (TL) and 1.6 years, respectively (Froese and Pauly 2015). The parameters of the allometric lengthweight relationship estimated by Froese et al. (2013) are $a$ $=0.01259(0.00508-0.03119)$ and $b=3.03(2.81-3.25)$. Other life history and population characters of $C$. walteri include: Trophic level $=2.42 ;$ Natural mortality $=0.961 /$ year; Life $\operatorname{span}=6$ years; Length to infinity $=284 \mathrm{~mm}$; Minimum population doubling time $=<15$ months (Froese and Pauly, 2015). The species is considered to be an omnivorous feeder (Froese and Pauly, 2015).

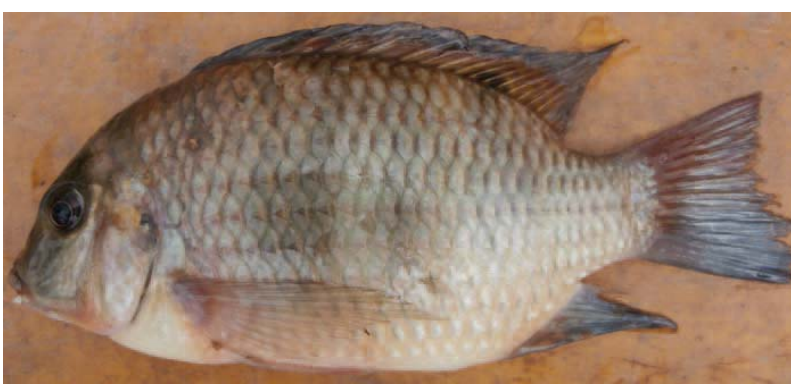

Fig. 1. Coptodon walteri from the Cavally River (Photo courtesy of Felix Koffi Konan)

\section{THREATS}

Segments of the Cavally River suffer from strong anthropogenic pressure mainly related to gold mining. This intensive gold mining activity by using motorized equipment in the river bed has led to water pollution, destabilization of riverbanks, disruption of ecosystem functioning, modification of the substrate, high noise levels and high concentration of suspended solids.

Overharvest is also a major threat to the species given its importance as a food fish (Konan, 2015; Konan et al., 2015).

\section{USE AND TRADE}

Caught by artisanal fishers in the Danane region of Ivory Coast (Doffou, 2014; Konan, 2015; Konan et al., 2015).

The species is consumed by the local population because of its fresh flesh that is much appreciated. As such, it is a commercially important food fish, an important source of animal protein and micronutrients in the diet of riparian rural populations.

\section{CONSERVATION ACTIONS}

Research has been initiated on aspects of the biometrics, length-weight relationship, condition factor, reproduction, feeding ecology and population dynamics of C. walteri (Doffou, 2014; Konan, 2015; Konan et al., 2015).

Moreover, mining activities in this area must be regulated and must respect the Performance Standard 6 (IFC, 2012) concerning the conservation of biodiversity and sustainable management of natural living resources.

\section{ACKNOWLEDGEMENTS}

The authors would like to express their gratitude to the SMI-La Mancha, 2D-Consulting Afrique and Division Environnement - SNC-Lavalin INC for financial supports of sampling in the Cavally River, Ivory Coast. The authors would also like to thank the reviewers for helping improve the paper.

\section{Sažetak}

\section{UGROŽENE VRSTE RIBA U SVIJETU: Coptodon walteri (Thys van den Audenaerde 1968) (Perciformes: Cichlidae)}

Coptodon walteri, Thys van den Audenaerde, 1968, je endemski ciklid iz Obale Bjelokosti i Liberije koji je ocijenjen kao gotovo ugrožena vrsta zbog ribolovnog pritiska, gubitka staništa i zagađenja vode zbog opsežnog iskapanja zlata u koritu rijeke Cavally. Iskazana je izrazita potreba za izradom planova zaštite i upravljanja za ovu vrstu.

Ključne riječi: Tilapia walteri, ciklid, gotovo ugrožena vrsta, zapadna Afrika

\section{REFERENCES}

Baensch, H. A., Riehl, R. (1995): Aquarien Atlas. Band 4. Mergus Verlag $\mathrm{GmbH}$, Verlag für Natur-und Heimtierkunde, Melle, Germany. 864 pp.

Doffou, R. J. O. (2014): Biodiversité de la faune ichtyologique du fleuve Cavally à Ity (Côte d'Ivoire). Master biodiversité et valorisation des écosystčmes de l'Université 
Felix Houphouet Boigny, Spécialité: Hydrobiobiologie, $\mathrm{n}^{\circ}$ d'ordre 54/2014. 51p.

Dunz, R. A., Schliewen, K. U. (2013): Molecular phylogeny and revised classification of the haplotilapiine cichlid fishes formerly referred to as "Tilapia”. Molecular Phylogenetics and Evolution, 68, 1, 64-80.

Eschmeyer, W. N., Fricke R., van der Laan R. (Eds). (2016): Catalog of fishes: genera, species, references. (Electronic version accessed on 15 April 2016) (http://researcharchive.calacademy.org/research/ichthyology/catalog/ fishcatmain.asp).

Froese, R., Pauly, D. (Eds). (2015): FishBase. World Wide Web electronic publication. (Electronic version accessed on 15 December 2015) www.fishbase.org, version (10/2015).

Froese, R., Thorson, J., Reyes Jr. R. B. (2013): A Bayesian approach for estimating length-weight relationships in fishes. Journal of Applied Ichthyology, 29, 1-7.

Holland, R. A., Darwall, W. R. T., Smith, K. G. (2012): Conservation priorities for freshwater biodiversity: the Key Biodiversity Area approach refined and tested for continental Africa. Biological Conservation, 148, 167-179.

IFC (2012): Guidance Note 6 Biodiversity Conservation and Sustainable Management of Living Natural Resources. Performance Standards and Guidance Notes - 2012 Edition. Internationale Finance Corporation. 69 pp.

IUCN (2014): IUCN Red List of Threatened Species. Version 2014. 1. IUCN 2014. IUCN Red List of Threatened Species. Downloaded in June 2014.

Konan, K. F. (2015): Inventaire ciblé des espčces de poissons d'intérêt pour la conservation - Fleuve Cavally dans la zone d'influence des activités d'extension de la Société des Mines d'Ity (SMI) (Côte d'Ivoire). Rapport d'étude -
Société des Mines d'Ity (SMI), Division Environnement - Cabinet SNC-Lavalin INC, Université Jean Lorougnon Guédé. 34 pp.

Konan, K. F., Niamen-Ebrottié, J. E., Bony, K. Y., Assemian, N. E. (2015): Etude hydrobiologique du fleuve Cavally / Etude d'Impact Environnemental et Social du Projet d'extension des activités de la Société des Mines d'Ity (SMI) (Côte d'Ivoire). Rapport d'étude - Société des Mines d'Ity (SMI), Cabinet 2D Consulting Afrique, Division Environnement - Cabinet SNC-Lavalin INC. $74 \mathrm{pp}$.

Thys van den Audenaerde, D. F. E. (1968): Description de Tilapia walteri sp. n. (Pisces, Cichlidae), de la rivičre Cavally (Afrique Occidentale). Revue de Zoologie et de Botanique Africaines, 78, 3-4, 374-379.

Teugels, G. G., Thys van den Audenaerde, D. F. E. (1991): Tilapia. pp. 482-508. In: Daget, J., Gosse, J.-P., Teugels, G. G., Thys van den Audenaerde D. F. E. (Eds). Check-list of the freshwater fishes of Africa (CLOFFA). ISNB, Brussels; MRAC, Tervuren; and ORSTOM, Paris. Vol. 4.

Teugels, G. G., Thys van den Audenaerde, D. F. E. (1992): Cichlidae. pp. 714-779. In: Levêque, C., Paugy, D., Teugels, G.G. (Eds), Faune des poissons d'eaux douces et saumâtres d'Afrique de l'Ouest. Tome 2. Coll. Faune Tropicale $n^{\circ} 28$. Musée Royal de l'Afrique Centrale, Tervuren, Belgique and ORSTOM, Paris. 902 pp.

Teugels, G. G., Thys van den Audenaerde, D. F. E. (2003): Cichlidae. pp. 521-600. In: Paugy, D., Lévêque, C., Teugels, G.G. (Eds). The fresh and brackish water fishes of West Africa Volume 2. Coll. faune et flore tropicales 40. Institut de recherche de développement, Paris, France, Muséum national d'histoire naturelle, Paris, France and Musée royal de l'Afrique Central, Tervuren, Belgium. 815 pp. 